\title{
A Novel Bispecific Immunotoxin Delivered by Human Bone Marrow-Derived Mesenchymal Stem Cells to Target Blood Vessels and Vasculogenic Mimicry of Malignant Gliomas [Retraction]
}

\author{
Zhang Y, Sun X, Huang M, Ke Y, Wang J, Liu X. Drug \\ Des Devel Ther. 2015;9:2947-2959.
}

At the request of the authors, the Editor and Publisher of Drug Design, Development and Therapy wish to retract the published article. Concerns were raised regarding duplicated mouse images and cell staining images in Figures 4A and 5A, respectively. The authors were unable to locate the original data for their study and thus were unable to verify the validity of the data.
To ensure the integrity of the publication record the authors requested to retract the paper and the editor has agreed with this decision.

Our decision-making was informed by our policy on publishing ethics and integrity and the COPE guidelines on retraction.

The retracted article will remain online to maintain the scholarly record, but it will be digitally watermarked on each page as "Retracted".

\section{Publish your work in this journal}

Drug Design, Development and Therapy is an international, peerreviewed open-access journal that spans the spectrum of drug design and development through to clinical applications. Clinical outcomes, patient safety, and programs for the development and effective, safe, and sustained use of medicines are a feature of the journal, which has also been accepted for indexing on PubMed Central. The manuscript management system is completely online and includes a very quick and fair peer-review system, which is all easy to use. Visit http://www. dovepress.com/testimonials.php to read real quotes from published authors. 